\title{
Targeted testing for DNA/1 hot spot-mutation utilizing immunofluorescence microscopy findings
}

\author{
M Szczepaniak ${ }^{1,2,3^{*}}$, NT Loges ${ }^{3}$, H Olbrich ${ }^{3}$, M Witt ${ }^{1,2}$, H Omran $^{3}$ \\ From First International Cilia in Development and Disease Scientific Conference (2012) \\ London, UK. 16-18 May 2012
}

Primary ciliary dyskinesia (PCD) is a rare (prevalence $1 /$ 20,000) genetic disease affecting motile cilia in the respiratory epithelium, spermatozoid flagella and primary cilia in the embryonic node. The most frequent ( 60-70\%) structural defect identified by TEM in the cilia of PCD patients are abnormal dynein arms. Several genes can cause PCD, but the majority of mutations were found in DNAH5 and DNAI1 genes (respectively 28\% and 4-10\% of all cases), which encode heavy and intermediate chains of the outer dynein arms (ODAs), respectively. Mutations in both genes account collectively for almost $40 \%$ of PCD cases [Olbrich et al. 2002, Hornef et al. 2006, Zariwala et al. 2006, Zietkiewicz et al. 2010]. The hot-spot mutation in the DNAI1 gene appears in intron 1, with the frequency of the most popular mutation (IVS1+2_3insT, causes aberrant splicing) around $55 \%$ of all DNAI1 mutations. We have previously shown in a few PCD cases that proximal type-1 ODA complexes can be at least partially assembled in DNAI1 - mutant cilia [Fliegauf et al. 2005]. We analysed the frequency of this hot spot mutation among 51 patients, in which immunofluorescence has identified abnormal ODA staining (proximal presence of DNAH5). The prevalence of the mutation in intron 1 of DNAI1 gene will be confirmed by PCR and restriction enzyme digestion. In addition, we analyzed respiratory cilia for the inner dynein arm component DNALI1 localization, which we expect not to be altered in DNAI1 mutant cilia, contrasting the findings present in $K T U$ - mutant cilia.

\section{Author details}

'Department of Clinical and Molecular Genetics, Institute of Human Genetics, Polish Academy of Sciences, Poznań, Poland. ${ }^{2}$ International Institute of Molecular and Cell Biology in Warsaw, Poland. ${ }^{3}$ Klinik und Poliklinik für

\footnotetext{
* Correspondence: malgorzata.szczepaniak@ukmuenster.de

'Department of Clinical and Molecular Genetics, Institute of Human Genetics, Polish Academy of Sciences, Poznań, Poland Full list of author information is available at the end of the article
}

Kinder- und Jugendmedizin -Allgemeine Pädiatrie-, Universitätsklinikum Münster, Germany.

Published: 16 November 2012

doi:10.1186/2046-2530-1-S1-P104

Cite this article as: Szczepaniak et al:: Targeted testing for DNA/1 hot spot-mutation utilizing immunofluorescence microscopy findings. Cilia 2012 1(Suppl 1):P104.
Submit your next manuscript to BioMed Central and take full advantage of:

- Convenient online submission

- Thorough peer review

- No space constraints or color figure charges

- Immediate publication on acceptance

- Inclusion in PubMed, CAS, Scopus and Google Scholar

- Research which is freely available for redistribution

Submit your manuscript at www.biomedcentral.com/submit
() Biomed Central
C Biomed Central 